Article

\title{
Highly Selective Oxygen/Nitrogen Separation Membrane Engineered Using a Porphyrin-Based Oxygen Carrier
}

\author{
Jiuli Han ${ }^{1,2}$, Lu Bai ${ }^{1}$, Bingbing Yang ${ }^{1,2}$, Yinge Bai ${ }^{1}$, Shuangjiang Luo ${ }^{1}$, Shaojuan Zeng ${ }^{1}$, \\ Hongshuai Gao ${ }^{1}$, Yi Nie ${ }^{1,3}$, Xiaoyan Ji ${ }^{4}$, Suojiang Zhang ${ }^{1,2, *}$ and Xiangping Zhang ${ }^{1,2, *}$ \\ 1 Beijing Key Laboratory of Ionic Liquids Clean Process, State Key Laboratory of Multiphase \\ Complex Systems, CAS Key Laboratory of Green Process and Engineering, Institute of Process Engineering, \\ Chinese Academy of Sciences, Beijing 100190, China \\ 2 School of Chemical Engineering, University of Chinese Academy of Sciences, Beijing 100049, China \\ 3 Zhengzhou Institute of Emerging Industrial Technology, Zhengzhou 450000, China \\ 4 Energy Engineering, Division of Energy Science, Luleå University of Technology, 97187 Luleå, Sweden \\ * Correspondence: sjzhang@ipe.ac.cn (S.Z.); xpzhang@ipe.ac.cn (X.Z.); Tel.: +86-10-82627080 (S.Z.); \\ $+86-10-82544875$ (X.Z.)
}

Received: 16 August 2019; Accepted: 30 August 2019; Published: 3 September 2019

\begin{abstract}
Air separation is very important from the viewpoint of the economic and environmental advantages. In this work, defect-free facilitated transport membranes based on poly(amide-12-b-ethylene oxide) (Pebax-2533) and tetra( $p$-methoxylphenyl)porphyrin cobalt chloride $\left(\mathrm{T}\left(p-\mathrm{OCH}_{3}\right) \mathrm{PPCoCl}\right)$ were fabricated in systematically varied compositions for $\mathrm{O}_{2} / \mathrm{N}_{2}$ separation. $\mathrm{T}\left(p-\mathrm{OCH}_{3}\right) \mathrm{PPCoCl}$ was introduced as carriers that selectively and reversibly interacted with $\mathrm{O}_{2}$ and facilitated $\mathrm{O}_{2}$ transport in the membrane. The $\mathrm{T}\left(p-\mathrm{OCH}_{3}\right) \mathrm{PPCoCl}$ had good compatibility with the Pebax-2533 via the hydrogen bond interaction and formed a uniform and thin selective layer on the substrate. The $\mathrm{O}_{2}$ separation performance of the thin film composite (TFC) membranes was improved by adding a small amount of the $\mathrm{T}\left(p-\mathrm{OCH}_{3}\right) \mathrm{PPCoCl}$ and decreasing the feed pressure. At the pressure of $0.035 \mathrm{MPa}$, the $\mathrm{O}_{2}$ permeability and $\mathrm{O}_{2} / \mathrm{N}_{2}$ selectivity of the $0.6 \mathrm{wt} \%$ $\mathrm{T}\left(p-\mathrm{OCH}_{3}\right) \mathrm{PPCoCl} / \mathrm{Pebax}-2533$ was more than 3.5 times that of the Pebax-2533 TFC membrane, which reached the 2008 Robeson upper bound. It provides a candidate membrane material for $\mathrm{O}_{2} / \mathrm{N}_{2}$ efficient separation in moderate conditions.
\end{abstract}

Keywords: facilitated transport membranes; cobalt porphyrin; oxygen/nitrogen separation; mixed matrix membrane; selectivity

\section{Introduction}

Air separation is an essential process, in which the obtained oxygen-enriched air can be used to assist combustion by increasing the burning velocities [1], regenerate catalysts in the fluid catalytic cracking [2], and improve indoor air quality [3]; meanwhile, the obtained nitrogen-enriched air can be applied in keeping food fresh, preventing fires, oil recovery, and draining water $[4,5]$. Currently, cryogenic distillation is the commercial and mature technology for air separation, which can produce a large amount of high purity ( $>99 \%$ ) oxygen and nitrogen. However, this process is complex, as well as cost and energy intensive [6]. Pressure swing adsorption (PSA) is another commonly used air separation method that can produce high purity $(\approx 95 \%)$ oxygen with medium production, but the larger space, higher investment, and energy consumption of the process are still challenging [7]. Compared with these air separation technologies, the membrane gas separation method is a green and sustainable process because of its continuous production, easy operation, small space, environmental friendliness, 
and energy conservation [7-11]. Polymeric membranes are usually applied for air separation, but their gas separation performance is always limited by the Robeson upper bound between $\mathrm{O}_{2}$ permeability and $\mathrm{O}_{2} / \mathrm{N}_{2}$ selectivity [12]. Therefore, developing membranes with both excellent $\mathrm{O}_{2}$ permeability and $\mathrm{O}_{2} / \mathrm{N}_{2}$ selectivity for efficient air separation is highly desired.

Facilitated oxygen transport through membranes is an effective approach to enhance the separation performance or even overcome the Robeson upper bound. These membranes usually contain metal complexes as the oxygen carrier, like cobalt phthalocyanine [13], cobalt Schiff [14-16], and cobalt porphyrins [17-24]. They have a reversible interaction with $\mathrm{O}_{2}$, facilitating $\mathrm{O}_{2}$ transportation prior to other gases in membranes, so that the $\mathrm{O}_{2}$ separation performance is improved. Nagar et al. [13] prepared the facilitated transport membrane using cobalt phthalocyanine ( $\mathrm{CoPc}$ ) as the oxygen carrier and studied the effect of CoPc content and feed pressure on the $\mathrm{O}_{2} / \mathrm{N}_{2}$ separation performance. The $\mathrm{O}_{2}$ permeance and $\mathrm{O}_{2} / \mathrm{N}_{2}$ selectivity are up to $1.12 \mathrm{GPU}\left(1 \mathrm{GPU}=10^{-6} \mathrm{~cm}^{3} \mathrm{~cm}^{-2} \mathrm{~s}^{-1} \mathrm{cmHg}^{-1}\right)$ and 8.5 at the CoPc content of $1 \mathrm{wt} \%$ and the feed pressure of 2 bar. Matsuoka et al. [15] fabricated two kinds of liquid membranes with $\mathrm{N}, \mathrm{N}^{\prime}$-bis(salicylidene)ethylenediamine cobalt-based ionic liquid as the oxygen carrier. At a low feed pressure of $1 \mathrm{kPa}$, the $\mathrm{O}_{2} / \mathrm{N}_{2}$ separation performance overcomes the 2008 Robeson upper bound. Cobalt porphyrins were also applied as oxygen carriers owing to their high $\mathrm{O}_{2}$ affinity, easy preparation, and high stability. Yang et al. [19] investigated the effect of cobalt porphyrins with different substituents and axial ligands on the $\mathrm{O}_{2}$ permeability and $\mathrm{O}_{2} / \mathrm{N}_{2}$ ideal selectivity. The results showed the cobalt porphyrin containing an electron-accepting substituent $(-\mathrm{Cl})$ and imidazole as the ligand could increase the $\mathrm{O}_{2} / \mathrm{N}_{2}$ selectivity of the ethyl cellulose membrane. The $\mathrm{O}_{2}$ permeability and $\mathrm{O}_{2} / \mathrm{N}_{2}$ selectivity are 12.39 barrer and 4.44, respectively. This is due to the electron-accepting substituent $(-\mathrm{Cl})$ decreasing the electron density at the center cobalt ion via electron-inductive effects and decreasing the oxygen-binding rate, hence increasing the $\mathrm{O}_{2} / \mathrm{N}_{2}$ selectivity [20]. Shinohara et al. [21] prepared cobalt tetraazaporphyrin with a polymeric imidazole ligand and investigated its $\mathrm{O}_{2}$ separation performance, similarly showing that the low electron density at the cobalt ion leads to low oxygen-binding affinity and enhances the oxygen-releasing rate constant to elevate the $\mathrm{O}_{2}$ separation performance. The $\mathrm{O}_{2} / \mathrm{N}_{2}$ selectivity is up to 28 with a relatively low $\mathrm{O}_{2}$ permeability of 2.9 barrer. Shoji et al. [22] developed cobalt porphyrin-Nafion membranes and studied the $\mathrm{O}_{2} / \mathrm{N}_{2}$ separation performance. The results showed that the membrane containing cobalt porphyrin with the electron-accepting group -F (meso-tetrakis(pentafluorophenyl)porpyrinatocobalt, CoFPP) has a higher $\mathrm{O}_{2} / \mathrm{N}_{2}$ selectivity than that including meso-tetraphenylporphyrinatocobalt (CoTPP) as the carrier because the CoFPP has a lower oxygen-binding affinity than the CoTPP. Choi et al. [24] investigated the $\mathrm{O}_{2} / \mathrm{N}_{2}$ separation performance of the poly(n-butyl methacrylate)-cobalt tetraphenylporphyrin composite hollow fiber membrane and the $\mathrm{O}_{2}$ permeability and $\mathrm{O}_{2} / \mathrm{N}_{2}$ selectivity are $\approx 5.2$ barrer and 3.2, respectively. However, both the metalloporphyrin and polymer are solids. Their surface compatibility is still challenged and improved. Obviously, good compatibility is beneficial to the dispersion of the metalloporphyrin, increasing the $\mathrm{O}_{2}$ transport efficiency and then improving the membrane separation performance.

In this work, we developed a novel thin-film composite (TFC) membrane for $\mathrm{O}_{2} / \mathrm{N}_{2}$ separation, which was fabricated using the cobalt porphyrin $\left(\mathrm{T}\left(p-\mathrm{OCH}_{3}\right) \mathrm{PPCoCl}\right)$ as the oxygen carrier, Pebax-2533 as the polymer matrix, and macroporous PVDF as the support. The substitute $-\mathrm{OCH}_{3}$ connected to porphyrin was favorable for the compatibility between cobalt porphyrin and Pebax-2533. The cobalt porphyrin with $-\mathrm{Cl}$ as the axial ligand could decrease the electron density at the cobalt ion, and decrease the oxygen-binding affinity, hence enhance the oxygen-releasing rate to achieve the effective $\mathrm{O}_{2} / \mathrm{N}_{2}$ separation. The prepared TFC membranes were characterized, and the existing interaction between $\mathrm{T}\left(p-\mathrm{OCH}_{3}\right) \mathrm{PPCoCl}$ and $\mathrm{O}_{2}$ was proved via simulation. The influence of $\mathrm{T}\left(p-\mathrm{OCH}_{3}\right) \mathrm{PPCoCl}$ with different contents and different pressures on the $\mathrm{O}_{2}$ permeability, $\mathrm{N}_{2}$ permeability, and $\mathrm{O}_{2} / \mathrm{N}_{2}$ selectivity was systematically studied. 


\section{Materials and Methods}

\subsection{Materials}

The PVDF support membrane with a pore size of $0.1 \mu \mathrm{m}$ and an average thickness of $100 \mu \mathrm{m}$ was purchased from Hangzhou Anow Microfiltration Co., Ltd. (Hangzhou, China). Pebax-2533 containing $80 \mathrm{wt} \%$ of poly(tetramethylene oxide) (PTMEO) and $20 \mathrm{wt} \%$ of nylon 12 (PA12) was provided by Arkema (Paris, France), and its structure is shown in Chart 1a. The $\mathrm{N}_{2}(99.999 \%)$ and $\mathrm{O}_{2}$ (99.999\%) were supplied by Beijing Beiwen Gas Factory (Beijing, China). Hydrochloric acid, anhydrous methanol, and ethanol were purchased from Beijing Chemical Works (Beijing, China). o-nitrotoluene, $p$-anisaldehyde, propionic acid, and acetic acid were supplied by Aladdin (Shanghai, China). Pyrrole and anhydrous cobalt dichloride $\left(\mathrm{CoCl}_{2}\right)$ was purchased from Sinopharm Chemical Reagent Co., Ltd. (Shanghai, China). Dimethylformamide (DMF) was provided by Xilong Scientific Co., Ltd. (Guangdong, China). Deionized water was used throughout the study.

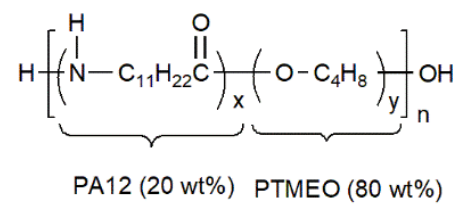

(a)

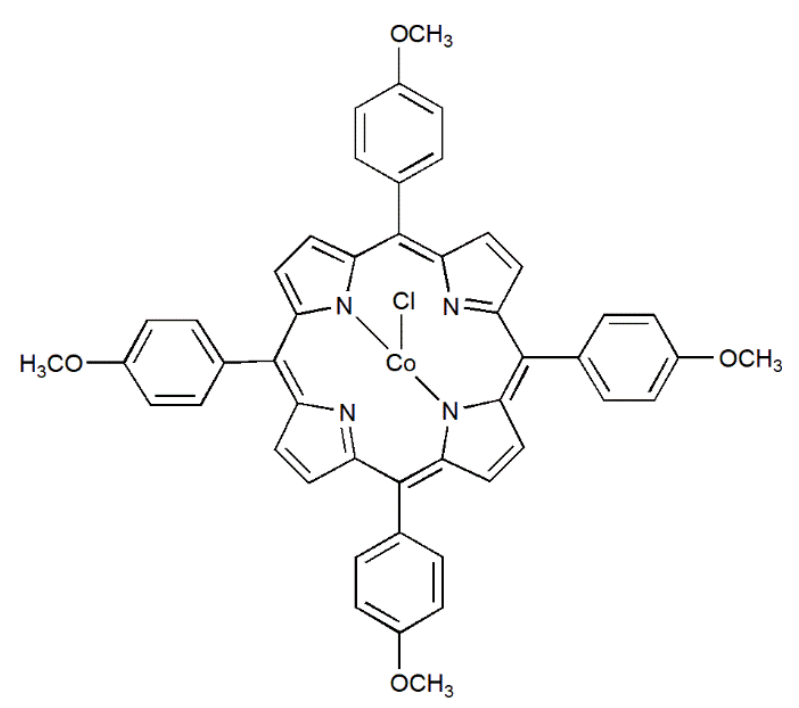

(b)

Chart 1. Chemical structures of Pebax-2533 (a) and $\mathrm{T}\left(p-\mathrm{OCH}_{3}\right) \mathrm{PPCoCl}(\mathbf{b})$.

\subsection{Synthesis of Cobalt Porphyrin}

Tetra $\left(p\right.$-methoxylphenyl)porphyrin $\left(\mathrm{T}\left(p-\mathrm{OCH}_{3}\right) \mathrm{PP}\right)$ was prepared according to the literature $[25,26]$ with some revisions. In a three-necked flask, propionic acid (20 mL), acetic acid (10 mL), and $o$-nitrotoluene $(10 \mathrm{~mL})$ were added. The mixture was heated to reflux, and then $p$-anisaldehyde (10 mmol) was added into the refluxing mixture and stirred for 5-6 min. Pyrrole (10 mmol) dissolved in $o$-nitrotoluene $(10 \mathrm{~mL})$ was added dropwise and reacted for $1 \mathrm{~h}$. The mixture was allowed to cool to $60{ }^{\circ} \mathrm{C}$, and then $30 \mathrm{~mL}$ of methanol was added slowly and set aside for recrystallization. The blue crystals were filtered and washed three times with water and methanol. The resulting T $(p-\mathrm{OCH})_{3} \mathrm{PP}$ product $\left(0.34 \mathrm{~g}, 18.5 \%\right.$ yield) was obtained and dried at $60^{\circ} \mathrm{C}$ under vacuum for $8 \mathrm{~h} .{ }^{1} \mathrm{H} \mathrm{NMR}(600 \mathrm{MHz}$, $\left.\mathrm{CDCl}_{3}\right) \delta(\mathrm{ppm}):-2.75(\mathrm{~s}, 2 \mathrm{H}) ; 4.10(\mathrm{~s}, 12 \mathrm{H}) ; 7.28(\mathrm{~d}, J=8.4 \mathrm{~Hz}, 8 \mathrm{H}) ; 8.12(\mathrm{~d}, J=8.4 \mathrm{~Hz}, 8 \mathrm{H}) ; 8.86(\mathrm{~s}, 8 \mathrm{H})$. 
Tetra( $p$-methoxylphenyl)porphyrin cobalt chloride $\left(\mathrm{T}\left(p-\mathrm{OCH}_{3}\right) \mathrm{PPCoCl}\right)$ (Chart $\left.1 \mathrm{~b}\right)$ was synthesized according to the literature [27]. T $\left(p-\mathrm{OCH}_{3}\right) \mathrm{PP}(147 \mathrm{mg}, 0.2 \mathrm{mmol}), \mathrm{DMF}(30 \mathrm{~mL})$ and acetic acid ( $3 \mathrm{~mL}$ ) were added into a three-necked flask and heated to reflux for $30 \mathrm{~min}$. Then, $\mathrm{CoCl}_{2}(156 \mathrm{mg}$, $1.2 \mathrm{mmol}$ ) was added with five portions and reacted for $5 \mathrm{~h}$. After the mixture was cooled down to room temperature, hydrochloric acid aqueous solution $(40 \mathrm{~mL}, \approx 19 \mathrm{wt} \%)$ was poured into the flask and held overnight for recrystallization. The crystals were filtered, washed thoroughly with hydrochloric acid aqueous solution $(200 \mathrm{~mL}, \approx 8 \mathrm{wt} \%)$, and dried at $60^{\circ} \mathrm{C}$ under vacuum for $8 \mathrm{~h}$ to obtain purple crystals of $\mathrm{T}\left(\mathrm{p}-\mathrm{OCH}_{3}\right) \mathrm{PPCoCl}(160 \mathrm{mg}$, yield $97 \%)$.

\subsection{Membrane Preparation}

Free-standing Pebax-2533 membrane and $\mathrm{T}\left(p-\mathrm{OCH}_{3}\right) \mathrm{PPCoCl} / \mathrm{Pebax}-2533$ mixed matrix membranes (MMMs) were prepared using a solution-casting method. Pebax-2533 pellets were dissolved in ethanol (10 wt \%) with magnetic stirring at $80^{\circ} \mathrm{C}$ for $3 \mathrm{~h}$. A predetermined amount of $\mathrm{T}\left(p-\mathrm{OCH}_{3}\right) \mathrm{PPCoCl}$ was then added and stirred at $40^{\circ} \mathrm{C}$ for $2 \mathrm{~h}$. After that, the solution was cast onto a glass dish and dried at room temperature for $24 \mathrm{~h}$ to form a sheet of membrane, which was further dried under vacuum at $60{ }^{\circ} \mathrm{C}$ for $8 \mathrm{~h}$.

TFC membranes of $\mathrm{T}\left(p-\mathrm{OCH}_{3}\right) \mathrm{PPCoCl} / \mathrm{Pebax}-2533$ on PVDF supports were prepared using a dip-coating method. Pre-weighed amounts of Pebax-2533 pellets were dissolved in hot ethanol at $80^{\circ} \mathrm{C}$ to obtain a homogeneous solution $(2 \mathrm{wt} \%)$. Then, $\mathrm{T}\left(p-\mathrm{OCH}_{3}\right) \mathrm{PPCoCl}$ was added and the mixture was stirred continuously at $40^{\circ} \mathrm{C}$ until it became homogeneous. The solution was degassed and poured into a glass cell. After that, the prefixed substrate PVDF on a glass pane was vertically immersed into the glass cell with the $\mathrm{T}\left(p-\mathrm{OCH}_{3}\right) \mathrm{PPCoCl} / \mathrm{Pebax}-2533$ solution and then dried at ambient temperature for $2 \mathrm{~h}$. Finally, the composite membranes were dried in a vacuum oven at $60^{\circ} \mathrm{C}$ for $8 \mathrm{~h}$ to remove any solvent residue.

\subsection{Characterization Methods}

Ultraviolet-visible (UV-Vis) spectra of $\mathrm{T}\left(p-\mathrm{OCH}_{3}\right) \mathrm{PP}$ and $\mathrm{T}\left(p-\mathrm{OCH}_{3}\right) \mathrm{PPCoCl}$ were recorded in toluene on a Shimadzu UV-2550 spectrophotometer (Shimadzu Corporation, Kyoto, Japan) in the range of $350-680 \mathrm{~nm}$. The Fourier transform infrared (FTIR) spectrum of $\mathrm{T}\left(p-\mathrm{OCH}_{3}\right) \mathrm{PPCoCl}$ and the attenuated total reflectance Fourier transform infrared (ATR-FTIR) spectra of Pebax-2533 and MMMs were obtained using a Thermo Nicolet 380 spectrometer (Thermo Electron Corporation, Madison, WI, USA) in the range of $650-4000 \mathrm{~cm}^{-1}$ under ambient conditions. Wide angle X-ray diffraction (WAXRD) patterns of the MMMs were measured using a Smartlab $(9 \mathrm{~kW})$ diffractometer (Rigaku Corporation, Tokyo, Japan) at a scan rate of $15^{\circ} \mathrm{min}^{-1}$; the $d$-spacing values were calculated based on the diffraction peak maxima using Bragg's equation. The surface and cross-sectional morphologies of the TFC membranes were observed using SU8020 scanning electron microscopy (SEM) (Hitachi High-Technologies Corporation, Tokyo, Japan). Before scanning, the membranes were fractured in liquid nitrogen and sputtered with gold.

The $\mathrm{O}_{2}$ and $\mathrm{N}_{2}$ permeation tests were carried out at ambient temperature using the standard constant-pressure, variable-volume method [28]. The feed pressure varied from 0.035 to $0.8 \mathrm{MPa}$ in gauge mode, and the permeate pressure was kept at atmospheric pressure. Gas permeability was calculated using the following equation:

$$
P=\frac{Q l}{t A\left(p_{1}-p_{2}\right)}
$$

where $P$ is the gas permeability (barrer, 1 barrer $=10^{-10}\left(\mathrm{~cm}^{3}\right.$ (STP) $\left.\mathrm{cm} \mathrm{cm}^{-2} \mathrm{~s}^{-1} \mathrm{cmHg}^{-1}\right), Q$ is the volume of permeated gas $\left(\mathrm{cm}^{3}(\mathrm{STP})\right), l$ is the film thickness $(\mathrm{cm}), t$ is the permeation time $(\mathrm{s}), A$ is the effective membrane area $\left(\mathrm{cm}^{2}\right)$, and $p_{1}$ and $p_{2}$ are the upstream and permeate side pressures $(\mathrm{cmHg})$, 
respectively. The ideal selectivity $(S)$ is defined as the ratio of the pure gas permeability of the faster gas $\mathrm{O}_{2}\left(P_{A}\right)$ over that of the slower permeant $\mathrm{N}_{2}\left(P_{B}\right)$ :

$$
S=\frac{P_{A}}{P_{B}}
$$

\subsection{Molecular Modeling}

Molecular geometries $\left(\mathrm{O}_{2}, \mathrm{~N}_{2}\right.$, and $\left.\mathrm{T}\left(p-\mathrm{OCH}_{3}\right) \mathrm{PPCoCl}\right)$ were optimized using density functional theory (DFT) calculations with Gaussian 09 software (Gaussian, Inc., Wallingford, CT, USA) [29]. The formation of complexes between $\mathrm{T}\left(p-\mathrm{OCH}_{3}\right) \mathrm{PPCoCl}$ and $\mathrm{N}_{2} / \mathrm{O}_{2}$ with several different structures were fabricated by locating $\mathrm{N}_{2}$ or $\mathrm{O}_{2}$ at different positions around $\mathrm{T}\left(p-\mathrm{OCH}_{3}\right) \mathrm{PPCoCl}$, and the energy minimizations of all complexes were implemented to determine the optimized geometry. All of the optimizations were explored at the B3LYP/6-311G $(d, p)$ level. The interaction energies between $\mathrm{T}\left(p-\mathrm{OCH}_{3}\right) \mathrm{PPCoCl}$ and $\mathrm{N}_{2} / \mathrm{O}_{2}$ were calculated at the same level.

\section{Results and Discussion}

\subsection{Synthesis and Characterization of $\mathrm{T}\left(\mathrm{p}-\mathrm{OCH}_{3}\right) \mathrm{PPCoCl}$}

$\mathrm{T}\left(p-\mathrm{OCH}_{3}\right) \mathrm{PP}$ was prepared in a mixed solvent of propionic acid, acetic acid, and $o$-nitrotoluene under an air atmosphere. Propionic acid and acetic acid were used as catalysts for the condensation of pyrrole and $p$-anisaldehyde to obtain porphyrinogen, which was further oxidized by the oxygen (air) and $o$-nitrotoluene to produce $\mathrm{T}\left(p-\mathrm{OCH}_{3}\right) \mathrm{PP}$ with a yield of $18.5 \%$. Compared with other metalloporphyrins, cobalt porphyrin has a higher stability [30]. Therefore, $\mathrm{T}\left(p-\mathrm{OCH}_{3}\right) \mathrm{PPCoCl}$ was used as the $\mathrm{O}_{2}$ carrier and prepared in DMF with a high yield $(97 \%)$. The obtained $\mathrm{T}\left(p-\mathrm{OCH}_{3}\right) \mathrm{PP}$ and $\mathrm{T}\left(p-\mathrm{OCH}_{3}\right) \mathrm{PPCoCl}$ were characterized using $\mathrm{UV}$-vis and the spectra are shown in Figure 1. $\mathrm{T}\left(p-\mathrm{OCH}_{3}\right) \mathrm{PP}$ exhibited a characteristic major Soret band at $422.8 \mathrm{~nm}$ owing to the $\pi \rightarrow \pi^{*}$ transition, and four visible $Q$ bands at 518.2, 554.7, 595.2, and $653.3 \mathrm{~nm}$. The Soret band of $\mathrm{T}\left(p-\mathrm{OCH}_{3}\right) \mathrm{PPCoCl}$ shifted to a longer wavelength of $441.7 \mathrm{~nm}$ and two $Q$ bands emerged at $556.8 \mathrm{~nm}$ and $596.1 \mathrm{~nm}$. The decreased amount of $\mathrm{Q}$ bands can be ascribed the metalation of $\mathrm{T}\left(p-\mathrm{OCH}_{3}\right) \mathrm{PP}$, which increased the molecular symmetry [31].

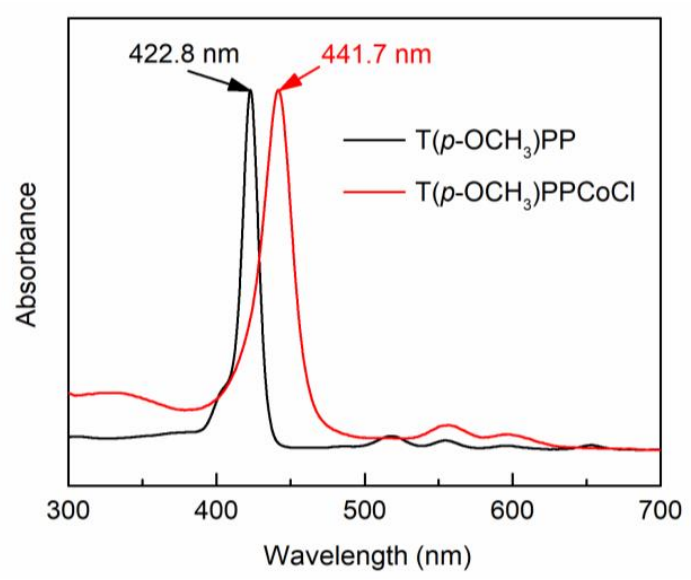

Figure 1. UV-vis spectra of $\mathrm{T}\left(p-\mathrm{OCH}_{3}\right) \mathrm{PP}$ and $\mathrm{T}\left(p-\mathrm{OCH}_{3}\right) \mathrm{PPCoCl}$.

\subsection{Membranes Properties and Characterizations}

The interaction between Pebax-2533 matrix and $\mathrm{T}\left(p-\mathrm{OCH}_{3}\right) \mathrm{PPCoCl}$ was investigated using FTIR, and the spectra of $\mathrm{T}\left(p-\mathrm{OCH}_{3}\right) \mathrm{PPCoCl}$, neat Pebax-2533 membrane, and $\mathrm{T}\left(p-\mathrm{OCH}_{3}\right) \mathrm{PPCoCl} / \mathrm{Pebax}-2533$ MMMs are given in Figure 2. The absorption peaks at 2834.0, 1606.2, 1351.2, 1248.8, and $1001.7 \mathrm{~cm}^{-1}$ for $\mathrm{T}\left(p-\mathrm{OCH}_{3}\right) \mathrm{PPCoCl}$ were assigned to $\mathrm{C}-\mathrm{H}, \mathrm{C}=\mathrm{C}, \mathrm{C}=\mathrm{N},-\mathrm{C}-\mathrm{O}-\mathrm{C}$, and $\mathrm{Co}-\mathrm{N}$ stretching vibrations, 
respectively. The spectrum of neat Pebax-2533 membrane was in accordance with the literature [32,33], in which the bands at 3307.9, 1734.7, 1638.2, and $1104.0 \mathrm{~cm}^{-1}$ represent the $\mathrm{N}-\mathrm{H}, \mathrm{C}=\mathrm{O}, \mathrm{H}-\mathrm{N}-\mathrm{C}=\mathrm{O}$, and $\mathrm{C}-\mathrm{O}$ stretching, respectively. The peak at $1248.8 \mathrm{~cm}^{-1}$ corresponds to the $-\mathrm{C}-\mathrm{O}-\mathrm{C}$ stretching vibration, which showed an increasing intensity with the increasing of the $\mathrm{T}\left(p-\mathrm{OCH}_{3}\right) \mathrm{PPCoCl}$ content in the MMMs, as expected. More importantly, the $-\mathrm{C}-\mathrm{O}-\mathrm{C}$ stretching vibration in $\mathrm{T}(p-\mathrm{OCH}) \mathrm{PPCoCl}$ shifted to a longer wavelength from 1248.8 to $1243.9 \mathrm{~cm}^{-1}$ in MMMs and the N-H stretching vibration in Pebax-2533 similarly shifted to a longer wavelength from 3307.9 to $3296.8 \mathrm{~cm}^{-1}$, confirming substantial hydrogen bonding was formed in the composite membranes [34]. The formation of hydrogen bonding could improve the affinity between $\mathrm{T}\left(p-\mathrm{OCH}_{3}\right) \mathrm{PPCoCl}$ and Pebax-2533, thus avoiding interfacial defects .

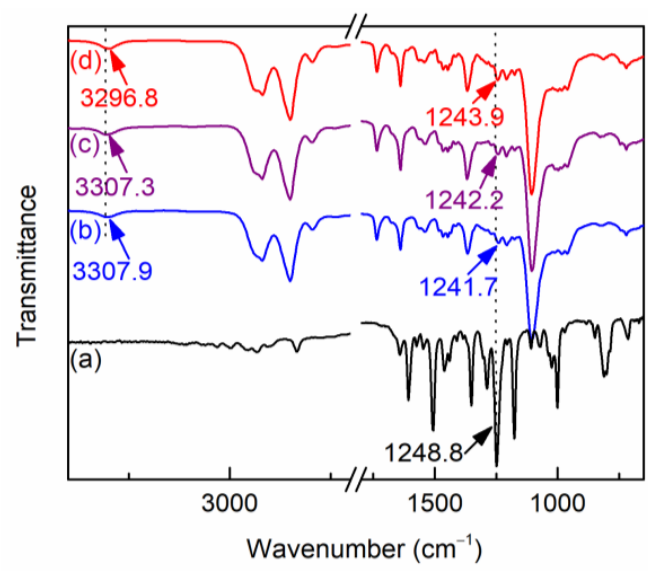

Figure 2. FTIR spectra of $\mathrm{T}\left(p-\mathrm{OCH}_{3}\right) \mathrm{PPCoCl}(\mathbf{a})$, Pebax-2533 membrane (b), 0.6 wt \% $\mathrm{T}\left(p-\mathrm{OCH}_{3}\right) \mathrm{PPCoCl} / \mathrm{Pebax}-2533$ membrane $(\mathbf{c})$ and $2 \mathrm{wt} \% \mathrm{~T}\left(p-\mathrm{OCH}_{3}\right) \mathrm{PPCoCl} / \mathrm{Pebax}-2533$ membrane (d).

To investigate the effect of $\mathrm{T}\left(p-\mathrm{OCH}_{3}\right) \mathrm{PPCoCl}$ on the chain packing structure of Pebax-2533, XRD patterns of the Pebax-2533 membrane, $0.6 \mathrm{wt} \% \mathrm{~T}\left(p-\mathrm{OCH}_{3}\right) \mathrm{PPCoCl} / \mathrm{Pebax}-2533 \mathrm{MMM}$ and 2 wt $\%$ $\mathrm{T}\left(p-\mathrm{OCH}_{3}\right) \mathrm{PPCoCl} /$ Pebax-2533 MMM were measured, as shown in Figure 3. The neat Pebax-2533 membrane had a broad peak located at $2 \theta=19.8^{\circ}$, which corresponds to a $d$-spacing value of $4.5 \AA$. The broad halo was identified as the inter-chain distance of amorphous regions [35-37]. Adding $\mathrm{T}\left(p-\mathrm{OCH}_{3}\right) \mathrm{PPCoCl}$ into Pebax-2533 matrix did not change the polymer chain packing structure, as evidenced in Figure 3, where the $d$-spacing values of the MMMs were the same as that of the pure Pebax-2533 membrane. No crystal peak of $\mathrm{T}\left(p-\mathrm{OCH}_{3}\right) \mathrm{PPCoCl}$ was observed in the WAXD patterns. This could have originated from a small weight fraction of the $\mathrm{T}\left(p-\mathrm{OCH}_{3}\right) \mathrm{PPCoCl}$ and suggests a good compatibility in the $\mathrm{T}\left(p-\mathrm{OCH}_{3}\right) \mathrm{PPCoCl} / \mathrm{Pebax}-2533$ composite membranes.

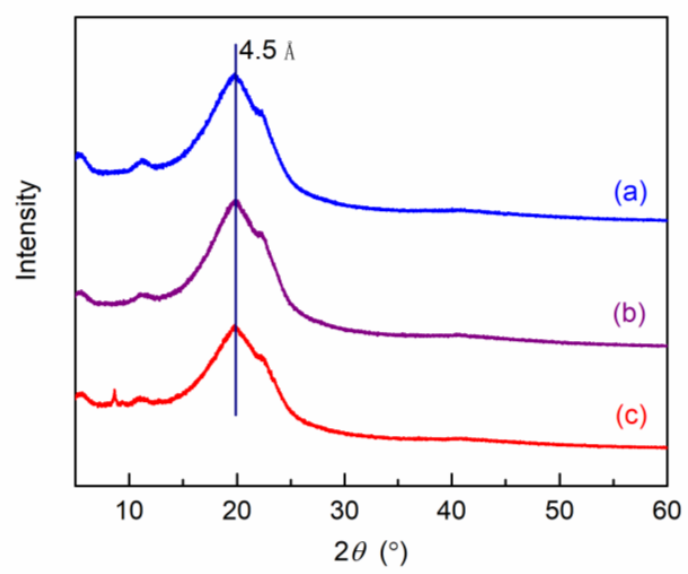

Figure 3. XRD spectra of Pebax-2533 membrane (a), 0.6 wt $\% \mathrm{~T}\left(p-\mathrm{OCH}_{3}\right) \mathrm{PPCoCl} / \mathrm{Pebax}-2533$ membrane (b), and 2 wt $\% \mathrm{~T}\left(p-\mathrm{OCH}_{3}\right) \mathrm{PPCoCl} /$ Pebax-2533 membrane (c). 
Figure 4 exhibits the surface and cross-sectional morphologies of the Pebax-2533 membrane and 0.6 wt \% T $\left(p-\mathrm{OCH}_{3}\right) \mathrm{PPCoCl} / \mathrm{Pebax}-2533 \mathrm{TFC}$ membrane. SEM images display homogeneous surfaces, and the cross-sectional view (Figure 4c) of Pebax-2533 shows two layers, i.e., the top selective layer with a film thickness of $1 \mu \mathrm{m}$ and the PVDF substrate. As shown in Figure $4 \mathrm{~b}, \mathrm{~d}$, no particulate clusters were observed, indicating that $\mathrm{T}\left(p-\mathrm{OCH}_{3}\right) \mathrm{PPCoCl}$ was well dispersed at the molecular level in the Pebax-2533 matrix without obvious agglomerations.
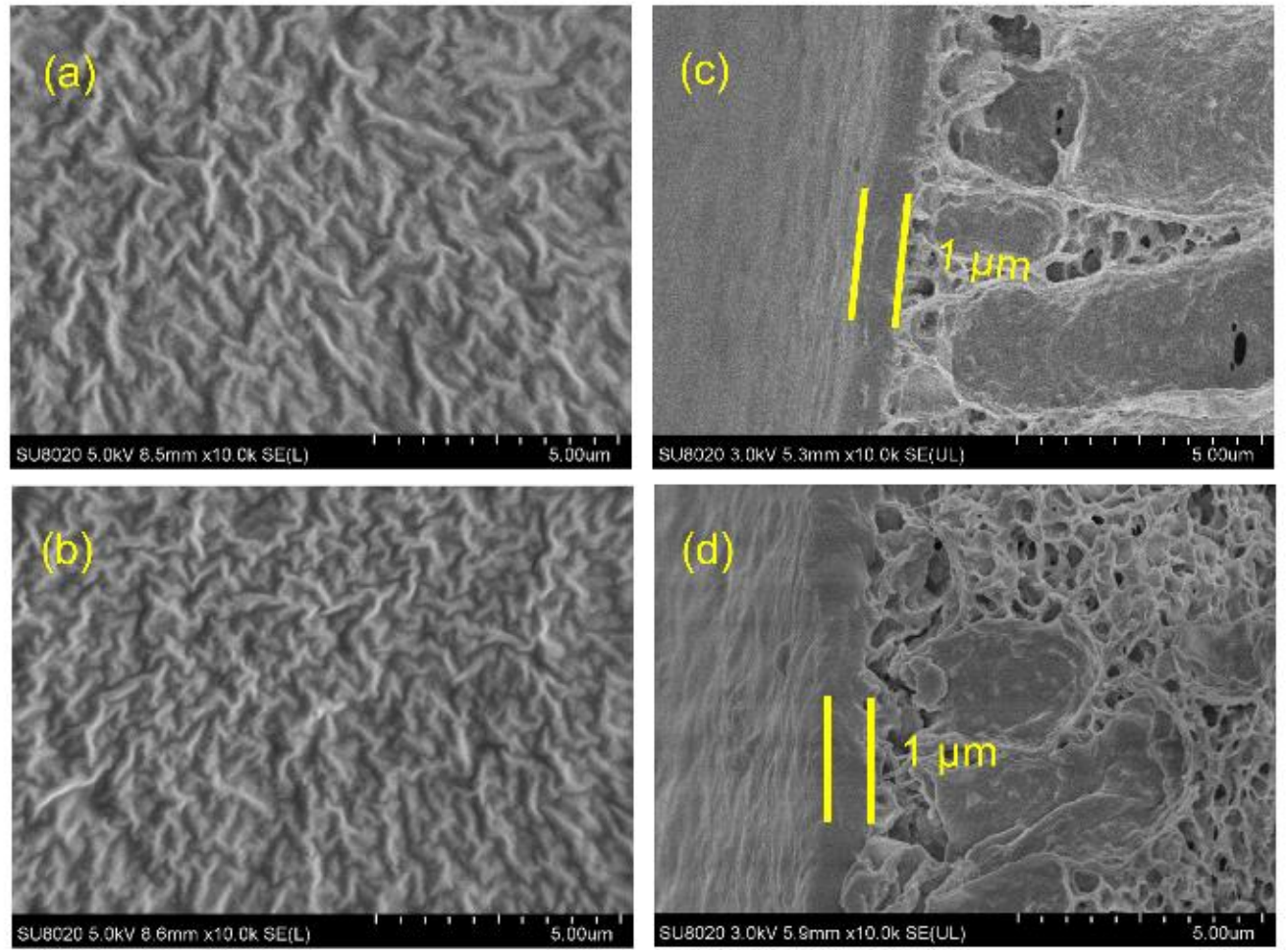

Figure 4. The surface SEM images of (a) Pebax-2533 membrane and (b) 0.6 wt \% $\mathrm{T}\left(p-\mathrm{OCH}_{3}\right) \mathrm{PPCoCl} /$ Pebax-2533 membrane, and the cross-section SEM images of (c) Pebax-2533 membrane and (d) $0.6 \mathrm{wt} \% \mathrm{~T}\left(p-\mathrm{OCH}_{3}\right) \mathrm{PPCoCl} / \mathrm{Pebax}-2533$ membrane.

\subsection{Molecular Modeling of $\mathrm{O}_{2} / \mathrm{N}_{2}$ and $\mathrm{T}\left(\mathrm{p}-\mathrm{OCH}_{3}\right) \mathrm{PPCoCl}$ Interactions}

The optimized structures of the $\mathrm{T}\left(p-\mathrm{OCH}_{3}\right) \mathrm{PPCoCl}$ and the interaction between $\mathrm{T}\left(p-\mathrm{OCH}_{3}\right) \mathrm{PPCoCl}$ and gas molecules were studied using molecular modeling, and the results are shown in Figure 5. $\mathrm{T}\left(p-\mathrm{OCH}_{3}\right) \mathrm{PPCoCl}$ exhibited a three-dimensional and distorted structure (Figure 5a), and it may have increased the fractional free volume and gas permeability of the membranes by disrupting the polymer chain packing. In the $\mathrm{T}\left(p-\mathrm{OCH}_{3}\right) \mathrm{PPCoCl}-\mathrm{N}_{2}$ complex (Figure $5 \mathrm{~b}$ ), the distance between 97Co and $120 \mathrm{~N}$ was $3.25 \AA$, and there was no obvious bond, confirming there was no interaction between $\mathrm{T}\left(p-\mathrm{OCH}_{3}\right) \mathrm{PPCoCl}$ and $\mathrm{N}_{2}$. However, in the $\mathrm{T}\left(p-\mathrm{OCH}_{3}\right) \mathrm{PPCoCl}-\mathrm{O}_{2}$ complex (Figure $\left.5 c\right), \mathrm{O}_{2}$ interacted with the central cobalt ion of $\mathrm{T}\left(p-\mathrm{OCH}_{3}\right) \mathrm{PPCoCl}$ to form a six-coordinate complex (Figure $5 \mathrm{c}$ ). The distance of $97 \mathrm{Co}-119 \mathrm{O}$ was $1.89 \AA$, which is the same as the length of the reported Co-O coordinate bond [38], showing the coordinate bond was formed between 97Co and 1190. It indicates there was an interaction between $\mathrm{T}\left(p-\mathrm{OCH}_{3}\right) \mathrm{PPCoCl}$ and $\mathrm{O}_{2}$. At the same time, the distance of $97 \mathrm{Co}-118 \mathrm{Cl}$ $(2.31 \AA)$ in the $\mathrm{T}\left(p-\mathrm{OCH}_{3}\right) \mathrm{PPCoCl}-\mathrm{O}_{2}$ complex was longer than that $(2.20 \AA)$ in $\mathrm{T}(p-\mathrm{OCH})_{3} \mathrm{PPCoCl}$ and shows the strength of the $97 \mathrm{Co}-118 \mathrm{Cl}$ bond decreased during the $\mathrm{T}\left(p-\mathrm{OCH}_{3}\right) \mathrm{PPCoCl}-\mathrm{O}_{2}$ complex formation. Their interaction energies between $\mathrm{T}\left(p-\mathrm{OCH}_{3}\right) \mathrm{PPCoCl}$ and $\mathrm{N}_{2}$ or $\mathrm{O}_{2}$ estimated using quantum chemical calculations were $-1.03 \mathrm{kcal} / \mathrm{mol}$ and $-23.54 \mathrm{kcal} / \mathrm{mol}$, respectively. It shows the interaction between $\mathrm{T}\left(p-\mathrm{OCH}_{3}\right) \mathrm{PPCoCl}$ and $\mathrm{O}_{2}$ was higher than that between $\mathrm{T}\left(p-\mathrm{OCH}_{3}\right) \mathrm{PPCoCl}$ and 
$\mathrm{N}_{2}$ and they may be reversible chemical and physical interactions separately. The reversible interaction makes $\mathrm{T}\left(\mathrm{p}-\mathrm{OCH}_{3}\right) \mathrm{PPCoCl}$ selectively adsorb oxygen and facilitate its transport in the membrane.
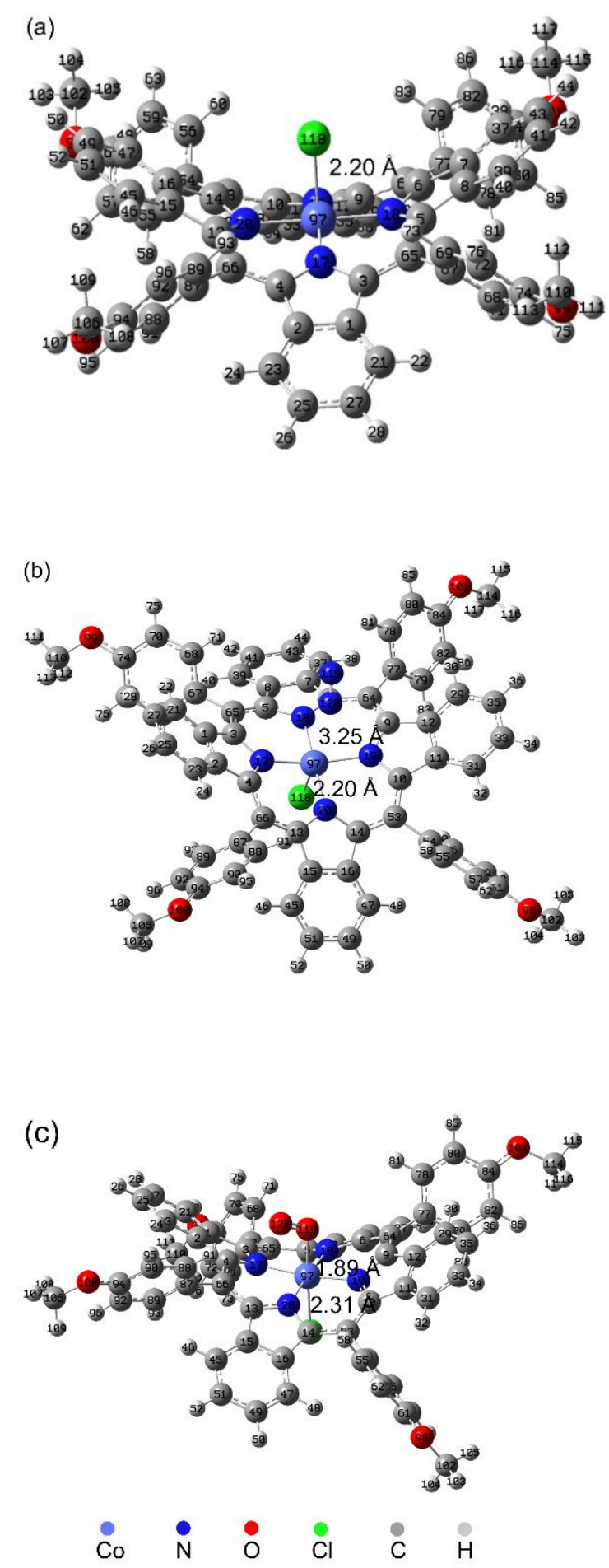

Figure 5. Optimized structures of (a) $\mathrm{T}\left(p-\mathrm{OCH}_{3}\right) \mathrm{PPCoCl},(\mathbf{b}) \mathrm{T}\left(p-\mathrm{OCH}_{3}\right) \mathrm{PPCoCl}-\mathrm{N}_{2}$ complex, and (c) $\mathrm{T}\left(p-\mathrm{OCH}_{3}\right) \mathrm{PPCoCl}-\mathrm{O}_{2}$ complex at the B3LYP/6-311G $(d, p)$ level.

\subsection{Gas Permeation Properties}

The influence of the $\mathrm{T}\left(p-\mathrm{OCH}_{3}\right) \mathrm{PPCoCl}$ content on $\mathrm{O}_{2}$ and $\mathrm{N}_{2}$ permeability and $\mathrm{O}_{2} / \mathrm{N}_{2}$ selectivity were systematically investigated. It can be seen from Figure $6 a$ that the $\mathrm{N}_{2}$ permeability increased with 
the increasing $\mathrm{T}\left(p-\mathrm{OCH}_{3}\right) \mathrm{PPCoCl}$ content. Given that there was almost no interaction between $\mathrm{N}_{2}$ and $\mathrm{T}\left(p-\mathrm{OCH}_{3}\right) \mathrm{PPCoCl}$ (interaction energy of $-1.03 \mathrm{kcal} / \mathrm{mol}$ ), the increase of the $\mathrm{N}_{2}$ permeability was mainly due to the increase of the free volume resulting from adding the twisted $\mathrm{T}\left(p-\mathrm{OCH}_{3}\right) \mathrm{PPCoCl}$ into the membrane. However, the $\mathrm{O}_{2}$ permeability first increased and then decreased with the increasing $\mathrm{T}\left(p-\mathrm{OCH}_{3}\right) \mathrm{PPCoCl}$ content. The $\mathrm{O}_{2}$ permeability of the $\mathrm{T}\left(p-\mathrm{OCH}_{3}\right) \mathrm{PPCoCl} / \mathrm{Pebax}-2533 \mathrm{TFC}$ membrane reached a maximum value of 9.7 barrer at $1.2 \mathrm{wt} \% \mathrm{~T}\left(p-\mathrm{OCH}_{3}\right) \mathrm{PPCoCl}$ content, which is about 2.6 times that of a pure Pebax-2533 membrane. The suitable interaction energy of $-23.54 \mathrm{kcal} / \mathrm{mol}$ between $\mathrm{O}_{2}$ and $\mathrm{T}\left(p-\mathrm{OCH}_{3}\right) \mathrm{PPCoCl}$ made $\mathrm{T}\left(p-\mathrm{OCH}_{3}\right) \mathrm{PPCoCl}$ selectively adsorb $\mathrm{O}_{2}$ and then release $\mathrm{O}_{2}$ quickly, thus facilitating the $\mathrm{O}_{2}$ transport in the membrane and enhancing the $\mathrm{O}_{2}$ separation performance. When the $\mathrm{T}\left(p-\mathrm{OCH}_{3}\right) \mathrm{PPCoCl}$ content was between $0-1.2 \mathrm{wt} \%$, there were more $\mathrm{T}\left(p-\mathrm{OCH}_{3}\right) \mathrm{PPCoCl}$ molecules to interact with $\mathrm{O}_{2}$ and facilitate its transport in the membrane with the increasing of $\mathrm{T}\left(p-\mathrm{OCH}_{3}\right) \mathrm{PPCoCl}$ content. Meanwhile, the addition of $\mathrm{T}\left(p-\mathrm{OCH}_{3}\right) \mathrm{PPCoCl}$ increased the free volume of the membranes. These led to an increase of the $\mathrm{O}_{2}$ permeability. However, when further increasing the $\mathrm{T}\left(p-\mathrm{OCH}_{3}\right) \mathrm{PPCoCl}$ content, the $\mathrm{O}_{2}$ permeability decreased, probably owing to the aggregation of $\mathrm{T}\left(p-\mathrm{OCH}_{3}\right) \mathrm{PPCoCl}$ particles. The $\mathrm{O}_{2} / \mathrm{N}_{2}$ selectivity also increased initially and then decreased with the $\mathrm{T}\left(p-\mathrm{OCH}_{3}\right) \mathrm{PPCoCl}$ content increase (Figure $\left.6 \mathrm{~b}\right)$. The $\mathrm{T}\left(p-\mathrm{OCH}_{3}\right) \mathrm{PPCoCl} / \mathrm{Pebax}-2533 \mathrm{TFC}$ membrane with the $\mathrm{T}\left(p-\mathrm{OCH}_{3}\right) \mathrm{PPCoCl}$ content of $0.6 \mathrm{wt} \%$ exhibited the maximum $\mathrm{O}_{2} / \mathrm{N}_{2}$ selectivity of 4.2 and a relatively high $\mathrm{O}_{2}$ permeability of 8.0 barrer.
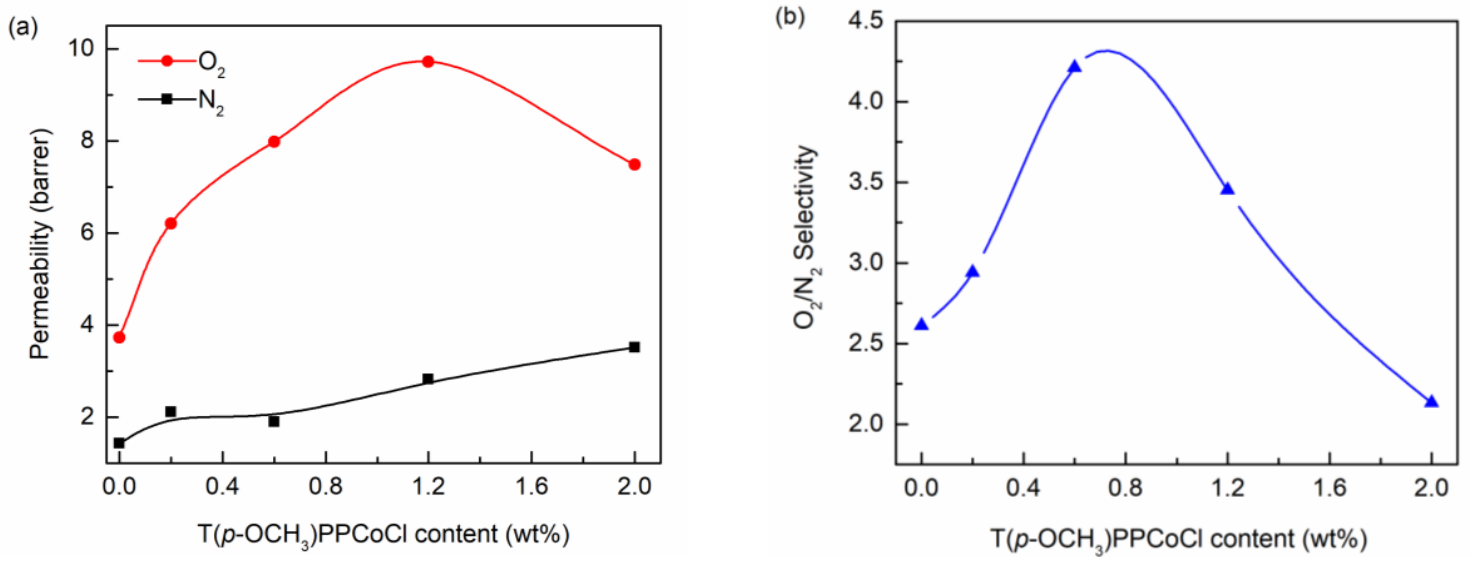

Figure 6. Effect of $\mathrm{T}\left(p-\mathrm{OCH}_{3}\right) \mathrm{PPCoCl}$ content on gas permeability (a) and $\mathrm{O}_{2} / \mathrm{N}_{2}$ selectivity (b).

Gas feed pressure also has a great influence on the $\mathrm{O}_{2}$ separation performance, and the results of the investigation is shown in Figure $7 a, b$. The $\mathrm{O}_{2}$ and $\mathrm{N}_{2}$ permeability of the membrane without $\mathrm{T}\left(p-\mathrm{OCH}_{3}\right) \mathrm{PPCoCl}$ almost remained constant when varying the feed pressure, indicating the change of pressure had no obvious influence. For the TFC membrane containing $0.6 \mathrm{wt} \% \mathrm{~T}\left(p-\mathrm{OCH}_{3}\right) \mathrm{PPCoCl}$, the $\mathrm{N}_{2}$ permeability increased slightly with the increasing feed pressure. The $\mathrm{O}_{2}$ permeability also remained constant when the feed pressure was higher than $0.1 \mathrm{MPa}$, but interestingly, the $\mathrm{O}_{2}$ permeability increased significantly from 8.0 barrer to 12.2 barrer, and the $\mathrm{O}_{2} / \mathrm{N}_{2}$ selectivity increased from 4.2 to 7.6 by lowering the feed pressure from $0.1 \mathrm{MPa}$ to $0.035 \mathrm{MPa}$. This indicates that the lower pressure was beneficial for $\mathrm{O}_{2}$ separation because the chemical interaction between $\mathrm{O}_{2}$ and the carrier was predominant at low feed pressure [39], hence promoting the oxygen transport by $\mathrm{T}\left(\mathrm{p}-\mathrm{OCH}_{3}\right) \mathrm{PPCoCl}$. 
(a)

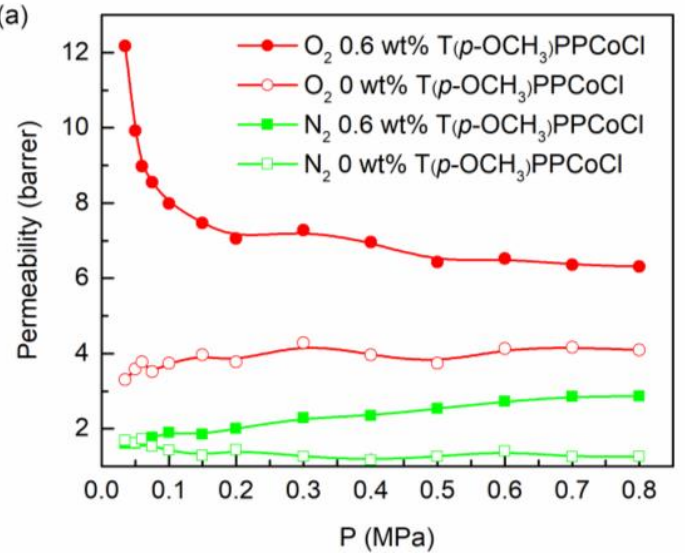

(b)

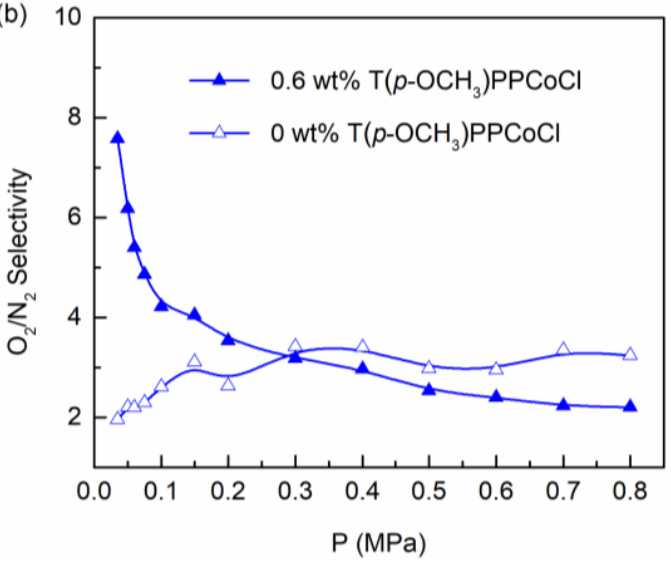

Figure 7. Effect of the feed pressure on gas permeability (a) and $\mathrm{O}_{2} / \mathrm{N}_{2}$ selectivity (b).

The $\mathrm{O}_{2} / \mathrm{N}_{2}$ separation performances of the $\mathrm{T}\left(p-\mathrm{OCH}_{3}\right) \mathrm{PPCoCl} / \mathrm{Pebax}-2533 \mathrm{TFC}$ membrane were plotted against the 2008 Robeson upper bound, as shown in Figure 8. Compared with the membrane without $\mathrm{T}\left(p-\mathrm{OCH}_{3}\right) \mathrm{PPCoCl}$, the adding of $\mathrm{T}\left(p-\mathrm{OCH}_{3}\right) \mathrm{PPCoCl}$ could enhance the separation performance mainly because $\mathrm{T}\left(p-\mathrm{OCH}_{3}\right) \mathrm{PPCoCl}$ could efficiently facilitate $\mathrm{O}_{2}$ transport in the membrane, as well as the non-planar $\mathrm{T}\left(p-\mathrm{OCH}_{3}\right) \mathrm{PPCoCl}$ increasing the gas permeability by increasing the fractional free volume. As the feed pressure was reduced, the separation performance was promoted gradually. The $\mathrm{O}_{2}$ permeability and $\mathrm{O}_{2} / \mathrm{N}_{2}$ selectivity were 12.2 barrer and 7.6, respectively, at $0.035 \mathrm{MPa}$, which is near the 2008 Robeson upper bound. For the facilitated membranes, lowering the feed pressure could enhance the separation performance. However, the separation performance of the $0.6 \mathrm{wt} \%$ $\mathrm{T}\left(p-\mathrm{OCH}_{3}\right) \mathrm{PPCoCl} / \mathrm{Pebax}-2533 \mathrm{TFC}$ membrane could reach the 2008 upper bound at a feed pressure of $35 \mathrm{kPa}$, which is higher than the feed pressures $(<20 \mathrm{kPa})$ of the reported lectures [15,19,21-23]. It shows the separation performance of the membrane could more easily reach the upper bound than the reported membranes by reducing the feed pressure. The separation performances of the reported membranes are presented in Table 1 for comparison. The data shows the $0.6 \mathrm{wt} \% \mathrm{~T}\left(p-\mathrm{OCH}_{3}\right) \mathrm{PPCoCl} / \mathrm{Pebax}-2533$ TFC membrane had satisfactory separation performance. Its $\mathrm{O}_{2} / \mathrm{N}_{2}$ selectivity was lower than only that of the $1 \mathrm{wt} \% \mathrm{CoPc} /$ Pebax-1657 membrane and $20 \mathrm{wt} \%$ CoFPP Nafion membrane, but its $\mathrm{O}_{2}$ permeance was much higher than theirs. Thus, the T $\left(p-\mathrm{OCH}_{3}\right) \mathrm{PPCoCl} / \mathrm{Pebax}-2533 \mathrm{TFC}$ membrane is a promising candidate for $\mathrm{O}_{2} / \mathrm{N}_{2}$ separation.

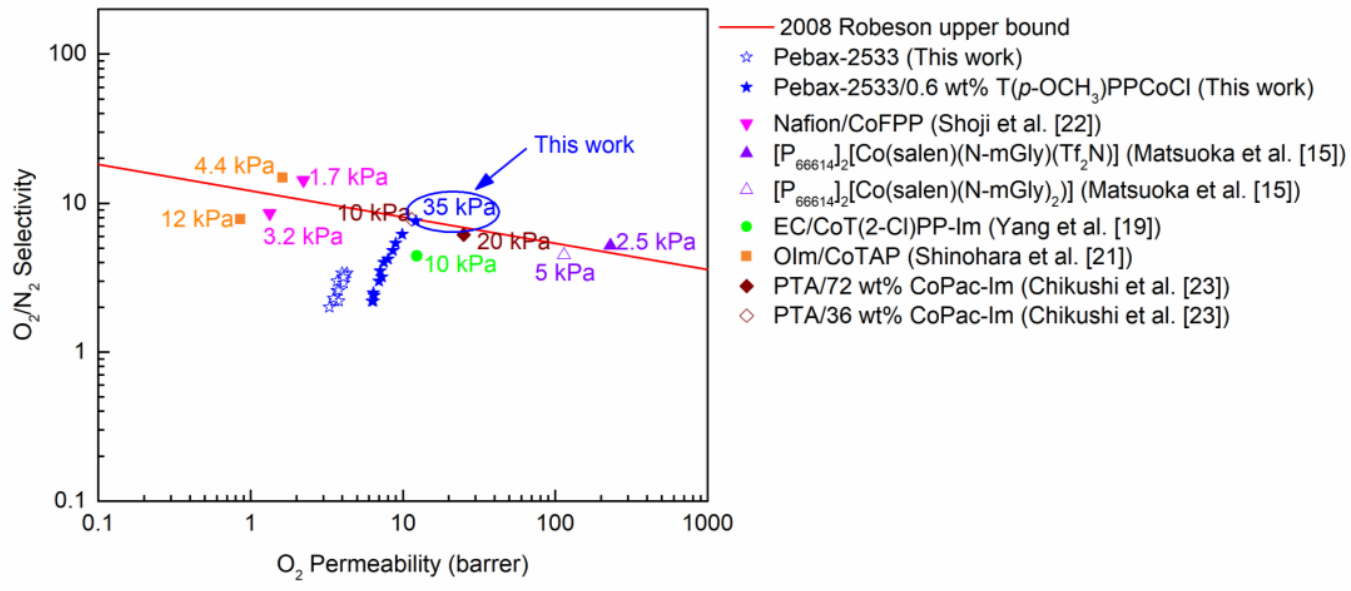

Figure 8. Performance comparison with the Robeson upper bound. 
Table 1. Comparison of the separation performance of the reported membranes with this work.

\begin{tabular}{|c|c|c|c|c|c|}
\hline Membrane & P (bar) & $\mathrm{T}\left({ }^{\circ} \mathrm{C}\right)$ & $\mathrm{S}_{\mathrm{O}_{2} / \mathbf{N}_{2}}$ & $\mathrm{P}_{\mathrm{O}_{2}}$ (barrer) ${ }^{a}$ & Ref. \\
\hline 1-15 wt \% MgPc/PEI & 12.8 & 25 & $\approx 2.3-5.4$ & $\approx 0.42-0.13 \mathrm{GPU}^{\mathrm{b}}$ & [40] \\
\hline $1-15$ wt $\%$ CoPc/PEI & 12.8 & 25 & $\approx 4.8-1.9$ & $\approx 0.25-1.13 \mathrm{GPU}$ & [40] \\
\hline $1 \mathrm{wt} \%$ cosalen/PU & 1 & $5-35$ & $\approx 4.2-3.0$ & $\approx 4.2-13.2$ & [41] \\
\hline 20 wt $\%$ CoFPP/Nafion & $1-2$ & 25 & $\approx 14.2-2.0$ & $\approx 2.2-0.3$ & [22] \\
\hline $\mathrm{SiO}_{2}-\mathrm{PVP}$-salcomine & - & $25-150$ & $1.4-6.1$ & 0.35-1.48 GPU & [14] \\
\hline 1 wt \% CoPc/Pebax-1657 & $2-8$ & 25 & $\approx 8.5-5.5$ & $\approx 1.12-0.93 \mathrm{GPU}$ & [13] \\
\hline $\begin{array}{c}0.6 \text { wt } \% \\
\mathrm{~T}\left(p-\mathrm{OCH}_{3}\right) \mathrm{PPCoCl} / \text { Pebax-2533 }\end{array}$ & $0.35-8$ & 18 & $7.6-2.2$ & $12.2-6.3$ & $\begin{array}{l}\text { This } \\
\text { study }\end{array}$ \\
\hline
\end{tabular}

\section{Conclusions}

$\mathrm{T}\left(p-\mathrm{OCH}_{3}\right) \mathrm{PPCoCl} / \mathrm{Pebax}-2533 \mathrm{TFC}$ membranes with a thin and defect-free active layer were prepared. The T $\left(p-\mathrm{OCH}_{3}\right) \mathrm{PPCoCl}$ and Pebax-2533 had good compatibility due to the formation of the hydrogen bond, improving the dispersion of the $\mathrm{T}\left(p-\mathrm{OCH}_{3}\right) \mathrm{PPCoCl}$ in Pebax-2533. $\mathrm{T}\left(p-\mathrm{OCH}_{3}\right) \mathrm{PPCoCl}$ as an oxygen carrier could not only facilitate oxygen transport due to the reversible interaction between $\mathrm{T}\left(p-\mathrm{OCH}_{3}\right) \mathrm{PPCoCl}$ and $\mathrm{O}_{2}$, but also increase the membrane free volume, enhancing the $\mathrm{O}_{2}$ and $\mathrm{N}_{2}$ permeability and $\mathrm{O}_{2} / \mathrm{N}_{2}$ selectivity. The $\mathrm{T}\left(p-\mathrm{OCH}_{3}\right) \mathrm{PPCoCl}$ content and feed pressure had a great influence on membrane separation performance. The $0.6 \mathrm{wt} \% \mathrm{~T}\left(p-\mathrm{OCH}_{3}\right) \mathrm{PPCoCl} / \mathrm{Pebax}-2533 \mathrm{TFC}$ membrane exhibited a better $\mathrm{O}_{2}$ permeability of 8.0 barrer and a $\mathrm{O}_{2} / \mathrm{N}_{2}$ selectivity of 4.2 than that of the TFC membrane without $\mathrm{T}\left(p-\mathrm{OCH}_{3}\right) \mathrm{PPCoCl}(3.7$ barrer and 2.6) at $0.1 \mathrm{MPa}$. Decreasing the feed pressure was beneficial for the $\mathrm{O}_{2}$ separation in the membrane. The $\mathrm{O}_{2}$ permeability and $\mathrm{O}_{2} / \mathrm{N}_{2}$ selectivity significantly increased to 12.2 barrer and 7.6 at $0.035 \mathrm{MPa}$, which is up to the 2008 Robeson upper bound.

Author Contributions: Conceptualization, S.Z. and X.Z.; Investigation, J.H.; Methodology, J.H. and B.Y.; Software, Y.B.; Writing-original draft, J.H.; Writing—review and editing, L.B., S.L., S.Z., H.G., Y.N., and X.J.

Funding: This work was supported by the National Key R\&D Program of China (2017YFB0603401-03), the National Natural Science Foundation of China (21978306, 21425625, 51574215), the Beijing Hundreds of Leading Talents Training Project of Science and Technology (Z171100001117154), the State Key Laboratory of Separation Membranes and Membrane Processes (Tianjin Polytechnic University) (M2-201808), and the Zhengzhou High Level Talent (No. 20180200029).

Conflicts of Interest: The authors declare that they have no conflict of interest.

\section{Abbreviations}

Pebax

$\mathrm{T}\left(p-\mathrm{OCH}_{3}\right) \mathrm{PPCoCl}$

PVDF

TFC

$\mathrm{CoPc}$

CoFPP

CoTPP

$\mathrm{T}\left(p-\mathrm{OCH}_{3}\right) \mathrm{PP}$

MMMs

$\mathrm{MgPc}$

PEI

PU

$\mathrm{SiO}_{2}-\mathrm{PVP}$-salcomine poly(amide-12-b-ethylene oxide)

tetra( $p$-methoxylphenyl)porphyrin cobalt chloride

polyvinylidene fluoride

thin film composite

cobalt phthalocyanine

meso-tetrakis(pentafluorophenyl)porpyrinatocobalt

meso-tetraphenylporphyrinatocobalt

tetra( $p$-methoxylphenyl)porphyrin

mixed matrix membranes

magnesium phathalocyanine

polyetherimide

polyurethane

$\mathrm{SiO}_{2}$-poly(N-vinylpyrrolidone)-(N,N-disalicylideneethylenediaminato)cobalt 


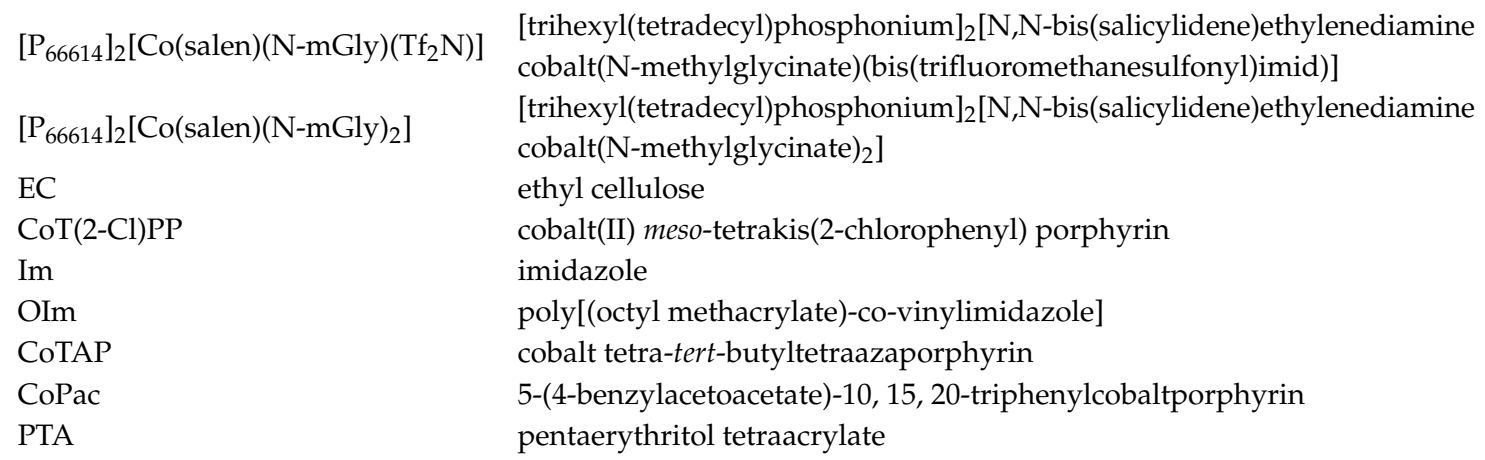

\section{References}

1. Cardona, C.A.; Amell, A.A. Laminar burning velocity and interchangeability analysis of biogas $/ \mathrm{C}_{3} \mathrm{H}_{8} / \mathrm{H}_{2}$ with normal and oxygen-enriched air. Int. J. Hydrogen Energy 2013, 38, 7994-8001. [CrossRef]

2. Caro, J. Oxygen-Enriched Air (OEA) Production by Membrane Reactors. In Encyclopedia of Membranes; Drioli, E., Giorno, L., Eds.; Springer: Heidelberg, Berlin, Germany, 2016; pp. 1446-1447. ISBN 978-3-662-44324-8.

3. Chong, K.C.; Lai, S.O.; Lau, W.J.; Thiam, H.S.; Ismail, A.F.; Zulhairun, A.K. Fabrication and Characterization of Polysulfone Membranes Coated with Polydimethysiloxane for Oxygen Enrichment. Aerosol Air Qual. Res. 2017, 17, 2735-2742. [CrossRef]

4. Hemmati-Sarapardeh, A.; Mohagheghian, E. Modeling interfacial tension and minimum miscibility pressure in paraffin-nitrogen systems: Application to gas injection processes. Fuel 2017, 205, 80-89. [CrossRef]

5. Frank, M.; Drikakis, D. Draining Water from Aircraft Fuel Using Nitrogen Enriched Air. Energies 2018, 11, 908. [CrossRef]

6. Wang, Y.; Yang, R.T. Chemical Liquid Deposition Modified 4A Zeolite as a Size-Selective Adsorbent for Methane Upgrading, $\mathrm{CO}_{2}$ Capture and Air Separation. ACS Sustain. Chem. Eng. 2019, 7, 3301-3308. [CrossRef]

7. Belaissaoui, B.; Le Moullec, Y.; Hagi, H.; Favre, E. Energy efficiency of oxygen enriched air production technologies: Cryogeny vs membranes. Sep. Purif. Technol. 2014, 125, 142-150. [CrossRef]

8. Hu, T.; Zhou, H.; Peng, H.; Jiang, H. Nitrogen Production by Efficiently Removing Oxygen From Air Using a Perovskite Hollow-Fiber Membrane With Porous Catalytic Layer. Front. Chem. 2018, 6, 329. [CrossRef] [PubMed]

9. Chong, K.C.; Lai, S.O.; Thiam, H.S.; Teoh, H.C.; Heng, S.L. Recent progress of oxygen nitrogen separation using membrane technology. J. Eng. Sci. Technol. 2016, 11, 1016-1030.

10. Wang, H.H.; Werth, S.; Schiestel, T.; Caro, A. Perovskite hollow-fiber membranes for the production of oxygen-enriched air. Angew. Chem. Int. Ed. 2005, 44, 6906-6909. [CrossRef]

11. Dong, G.; Zhang, X.; Zhang, Y.; Tsuru, T. Enhanced Permeation through $\mathrm{CO}_{2}$-Stable Dual-Inorganic Composite Membranes with Tunable Nanoarchitectured Channels. ACS Sustain. Chem. Eng. 2018, 6, 8515-8524. [CrossRef]

12. Robeson, L.M. The upper bound revisited. J. Membr. Sci. 2008, 320, 390-400. [CrossRef]

13. Nagar, H.; Vadthya, P.; Prasad, N.S.; Sridhar, S. Air separation by facilitated transport of oxygen through a Pebax membrane incorporated with a cobalt complex. RSC Adv. 2015, 5, 76190-76201. [CrossRef]

14. Kuraoka, K.; Chujo, Y.; Yazawa, T. A novel inorganic-organic hybrid membrane for oxygen/nitrogen separation containing a cobalt(II) Schiff base complex as oxygen carrier using poly(N-vinylpyrrolidone) as mediator. Chem. Commun. 2000, 24, 2477-2478. [CrossRef]

15. Matsuoka, A.; Kamio, E.; Mochida, T.; Matsuyama, H. Facilitated $\mathrm{O}_{2}$ transport membrane containing $\mathrm{Co}(\mathrm{II})$-salen complex-based ionic liquid as $\mathrm{O}_{2}$ carrier. J. Membr. Sci. 2017, 541, 393-402. [CrossRef]

16. Ruaan, R.C.; Chen, S.H.; Lai, J.Y. Oxygen/nitrogen separation by polycarbonate/Co(SalPr) complex membranes. J. Membr. Sci. 1997, 135, 9-18. [CrossRef]

17. Nishide, H.; Ohyanagi, M.; Okada, O.; Tsuchida, E. Highly Selective Transport of Molecular Oxygen in a Polymer Containing a Cobalt Porphyrin Complex as a Fixed Carrier. Macromolecules 1986, 19, 494-496. [CrossRef] 
18. Nishide, H.; Ohyanagi, M.; Okada, O.; Tsuchida, E. Dual-Mode Transport of Molecular Oxygen in a Membrane Containing a Cobalt Porphyrin Complex as a Fixed Carrier. Macromolecules 1987, 20, 417-422. [CrossRef]

19. Yang, J.P.; Huang, P.C. Facilitated transport of oxygen in ethyl cellulose membranes containing cobalt porphyrins as oxygen carriers. J. Appl. Polym. Sci. 2000, 77, 484-488. [CrossRef]

20. Yang, J.P.; Huang, P.C. A study of cobalt(II) porphyrins on their oxygen-binding behaviors and oxygen-facilitated transport properties in polymeric membranes. Chem. Mater. 2000, 12, 2693-2697. [CrossRef]

21. Shinohara, H.; Shibata, H.; Wohrle, D.; Nishide, H. Reversible oxygen binding to the polymeric cobalt tetraazaporphyrin complex and oxygen-facilitated transport through its membrane. Macromol. Rapid Commun. 2005, 26, 467-470. [CrossRef]

22. Shoji, M.; Oyaizu, K.; Nishide, H. Facilitated oxygen transport through a Nafion membrane containing cobaltporphyrin as a fixed oxygen carrier. Polymer 2008, 49,5659-5664. [CrossRef]

23. Chikushi, N.; Ohara, E.; Hisama, A.; Nishide, H. Porphyrin Network Polymers Prepared via a Click Reaction and Facilitated Oxygen Permeation Through Their Membranes. Macromol. Rapid Commun. 2014, 35, 976-980. [CrossRef] [PubMed]

24. Choi, W.; Ingole, P.G.; Li, H.; Kim, J.H.; Lee, H.K.; Baek, I.H. Preparation of facilitated transport hollow fiber membrane for gas separation using cobalt tetraphenylporphyrin complex as a coating material. J. Clean. Prod. 2016, 133, 1008-1016. [CrossRef]

25. Sun, Z.; She, Y.; Zhong, R. Synthesis of $p$-substituted tetraphenylporphyrins and corresponding ferric complexes with mixed-solvents method. Front. Chem. Eng. China 2009, 3, 457-461. [CrossRef]

26. Momo, P.B.; Bellete, B.S.; Brocksom, T.J.; De Souza, R.O.M.A.; De Oliveira, K.T. Exploiting novel process windows for the synthesis of meso-substituted porphyrins under continuous flow conditions. RSC Adv. 2015, 5, 84350-84355. [CrossRef]

27. Kumar, A.; Maji, S.; Dubey, P.; Abhilash, G.J.; Pandey, S.; Sarkar, S. One-pot general synthesis of metalloporphyrins. Tetrahedron Lett. 2007, 48, 7287-7290. [CrossRef]

28. Bhavsar, R.S.; Mitra, T.; Adams, D.J.; Cooper, A.I.; Budd, P.M. Ultrahigh-permeance PIM-1 based thin film nanocomposite membranes on PAN supports for $\mathrm{CO}_{2}$ separation. J. Membr. Sci. 2018, 564, 878-886. [CrossRef]

29. Frisch, M.J.; Trucks, G.W.; Schlegel, H.B.; Scuseria, G.E.; Robb, M.A.; Cheeseman, J.R.; Scalmani, G.; Barone, V.; Mennucci, B.; Petersson, G.A.; et al. Gaussian 09, Revision D. 01, Gaussian, Inc., Wallingford CT, 2013 Search PubMed;(b) AD Becke. J. Chem. Phys. 1993, 5648, 785-789.

30. Li, G.Q.; Govind, R. Separation of Oxygen from Air Using Coordination Complexes: A Review. Ind. Eng. Chem. Res. 1994, 33, 755-783. [CrossRef]

31. Chen, W.T.; El-Khouly, M.E.; Fukuzumi, S. Saddle Distortion of a Sterically Unhindered Porphyrin Ring in a Copper Porphyrin with Electron-Donating Substituents. Inorg. Chem. 2011, 50, 671-678. [CrossRef]

32. De Dai, Z.; Bai, L.; Hval, K.N.; Zhang, X.P.; Zhang, S.J.; Deng, L.Y. Pebax®/TSIL blend thin film composite membranes for $\mathrm{CO}_{2}$ separation. Sci. China Chem. 2016, 59, 538-546. [CrossRef]

33. Sridhar, S.; Aminabhavi, T.M.; Mayor, S.J.; Ramakrishna, M. Permeation of carbon dioxide and methane gases through novel silver-incorporated thin film composite Pebax membranes. Ind. Eng. Chem. Res. 2007, 46, 8144-8151. [CrossRef]

34. Wang, H.; Liu, S.; Zhao, Y.; Wang, J.; Yu, Z. Insights into the Hydrogen Bond Interactions in Deep Eutectic Solvents Composed of Choline Chloride and Polyols. ACS Sustain. Chem. Eng. 2019, 7, 7760-7767. [CrossRef]

35. Nafisi, V.; Hagg, M.B. Development of Nanocomposite Membranes Containing Modified Si Nanoparticles in PEBAX-2533 as a Block Copolymer and 6FDA-Durene Diamine as a Glassy Polymer. ACS Appl. Mater. Interfaces 2014, 6, 15643-15652. [CrossRef] [PubMed]

36. Nafisi, V.; Hagg, M.B. Development of dual layer of ZIF-8/PEBAX-2533 mixed matrix membrane for $\mathrm{CO}_{2}$ capture. J. Membr. Sci. 2014, 459, 244-255. [CrossRef]

37. Dong, L.; Zhang, C.; Bai, Y.; Shi, D.; Li, X.; Zhang, H.; Chen, M. High-Performance PEBA2533-Functional MMT Mixed Matrix Membrane Containing High-Speed Facilitated Transport Channels for $\mathrm{CO}_{2} / \mathrm{N}_{2}$ Separation. ACS Sustain. Chem. Eng. 2016, 4, 3486-3496. [CrossRef] 
38. Li, J.F.; Noll, B.C.; Oliver, A.G.; Scheidt, W.R. Structural Insights into Ligand Dynamics: Correlated Oxygen and Picket Motion in Oxycobalt Picket Fence Porphyrins. J. Am. Chem. Soc. 2012, 134, 10595-10606. [CrossRef] [PubMed]

39. Shentu, B.Q.; Nishide, H. Facilitated oxygen transport membranes of picket-fence cobaltporphyrin complexed with various polymer matrixes. Ind. Eng. Chem. Res. 2003, 42, 5954-5958. [CrossRef]

40. Kurdi, J.; Tremblay, A.Y. Improvement in polyetherimide gas separation membranes through the incorporation of nanostructured metal complexes. Polymer 2003, 44, 4533-4540. [CrossRef]

41. Chen, S.H.; Yu, K.C.; Houng, S.L.; Lai, J.Y. Gas transport properties of HTPB based polyurethane/cosalen membrane. J. Memb. Sci. 2000, 173, 99-106. [CrossRef]

(C) 2019 by the authors. Licensee MDPI, Basel, Switzerland. This article is an open access article distributed under the terms and conditions of the Creative Commons Attribution (CC BY) license (http://creativecommons.org/licenses/by/4.0/). 